\title{
IMPROVING STUDENTS' ABILITY IN WRITING NARRATIVE TEXT BY USING PICTURE SERIES FOR THE EIGHT GRADE STUDENTS OF JUNIOR HIGH SCHOOL
}

\author{
Tuti Andayani \\ SMP Negeri 03 Sindang Kelingi, Curup, Rejang Lebong \\ Email : tuttykinantihanif@gmail.com \\ Arono \\ Postgraduate English Program, Faculty of Teacher Training and Education, \\ University of Bengkulu \\ Email : dank_aron@yahoo.com
}

\begin{abstract}
In this collaborative Classroom Action Research (CAR), the researcher tried to overcome the problem of writing narrative text facing by the eight grade students in Junior High School, especially in getting and composing the ideas. The question of this research was 'Can Picture Series improve the students' ability in writing narrative text?' This class action research was divided into two cycles. Every cycle was divided into four stages, including (1) planning, (2) implementing, (3) observing, and (4) reflecting and it was focussedonthe students' ability in writing narrative text by getting idea from a picture and developing the idea with the guidance from a series of pictures. The samples were 20 students of SMP Negeri 03 Sindang Kelingi, Curup, and Rejang Lebong. The data which were got from the students' achievement in the cycle I and cycle II were analyzed by using quantitative analysis data technique. From the analysis, the writer founded that in the cycle I, students gain the average score 61,35 and in the cycle II the average score was 84,50.It is suggested for the Junior High School English teachers to apply this technique increasetheir students' ability in writing narrative text.
\end{abstract}

Keywords: Students'Ability, Writing, Narrative Text, Picture Series.

Abstrak: Dalam Penelitian Tindakan Kelas (PTK) ini, peneliti mencoba memecahkan permasalahan dalam menulis teks naratif yang dialami oleh para siswa Sekolah Menengah Pertama (SMP), khusunya kelas delapan. Banyak siswa menemui kesulitan dalam menulis teks naratif, terutama dalam mencari, menemukan dan menyusun ide-ide cerita. Rumusan masalah dalam penelitian ini adalah "Dapatkah gambar berseri meningkatkan kemampuan para siswa dalam menulis teks naratif?" Penelitian tindakan kelas ini terbagi menjadi dua siklus. Masing-masing siklus terdiri dari empat bagian, yaitu (1) perencanaan, (2) implementasi, (3) observasi, dan (4) refleksi serta berfokus pada meningkatkan kemampuan siswa menulis teks naratif dengan mendapatkan dan mengembangkan ide dari serangkaian gambar berseri. Sampel penelitian ini terdiri dari 20 siswa SMP Negeri 3 Sindang Kelingi, Curup, Rejang Lebong, Tahun Pelajaran 2014/2015. Data diambil dari pencapaian siswa dalam siklus I dan siklus II dan diolah dengan menggunakan teknik pengolah data kuantitatif. Dari analisis data, peneliti menemukan bahwa pada Siklus I, para siswa mendapatkan nilai rata-rata 61,35 dan pada Siklus II nilai rata-rata siswa adalah 84,50. Disimpulkan bahwa kemampuan para siswa menulis teks naratif meningkat dengan menggunakanan gambar berseri,sehingga teknik ini anjurkan untuk dipergunakan oleh para guru Bahasa Inggris di sekolah menengah pertama. 


\section{Kata Kunci: Kemampuan Siswa, Menulis Teks Naratif, Gambar Berseri.}

\section{INTRODUCTION}

Learning English for Indonesiansare not easy because it is a foreign language and it is not used in our everyday life. But in this world of globalization, many companies and large business employ people who are able to understand English both orally and written. That is why Indonesians, especially students, have to learn English more seriously in order to be able to communicate well and get good job in the future.

To solve this problem, the English teaching should be focused on the students' ability to communicate well through spoken and written. Spoken skill is the most important ability in communicating orally. But writing skill or written ability is also essential. Through written media, a writer can communicate with the readers. Suparno \& Mohamad Yunus (2006) stated that writing is an activity in delivery message (communication) like idea, concept, experience or information with written to other people. Thus, speaking activity and writing activity have the same goal, namely to deliver messages like idea, concept, experience or information to other people.

Students need to learn how to write well. By practicing writing, they can show their knowledge about the language they have learned. "Writing is used to prove that students have mastered a particular grammatical rule" (Nunan, 2003:89). The students should improve their knowledge about the strategy of writing anything in accepted way. It is really hoped that the students can learn how to put down words on paper as easily and naturally as they speak. Thus, they need to learn how to write any kinds of text in English and oneof thestrategies to reach this goal is by learning how to write a narrative text using picture series.

The English teachers seemed have difficulties in deciding what technique and media should be used in teaching writing appropriately. They have to be able to find the best way to make learning writing easier and enjoyable. It is the teacher's responsibility to facilitate the students in their learning process.

Actually, there are many kinds of text should be taught and many media can be used in teaching and learning how to write. Narrative text was chosen because it usually contains interesting story and the students of junior high school really like story. Picture series was chosen as a media because it was attractive and easy to get the students' attention. "Pictures give contribution to students' interest and motivation, sense of language in context, and stimulate students' ideas" (Wright, 1989).

Writing is perhaps the most difficult skill for students. Writing is also a complex activity. "Writing is a process that complex where the writer carries out exploration from various ideas, thought make your idea, and through become certain concrete" (Rusmajadi, 2010:229-230). While writing a big deal of attention should be given to correct spelling, grammar, punctuation and also the way of organizing the idea. Writing is a hard work that consists of some certain 
steps. "Writing is a process including a series of steps such as planning, organizing, drafting, revising, and editing" (Kirszen and Mandell, 2008:2090).

Planning includes setting goals and generating ideas. Organizing includes organizing information and selecting appropriate language. Drafting includes making the outlines and starting to compose the idea. Revising includes correcting the draft and rewriting it. Editing includes final correction on the draft and finishing it.

In order to consider the purpose of writing, a writer has to make sure what kind of genre to write. In Kurikulum Bahasa Inggris KTSP (2006), there are five kinds of text in junior high school to be learned, such as descriptive text, procedure text, recount text, narrative text, and report text.

Narrative text is learned in the eighth grade of the junior high school in the second semester. "Writing narrative is a kind of text to tell the activities or events in the past, which give priority to the problematic experience and resolution with the purpose to amuse and often be intended to give moral lesson for the reader" (Pardiyono, 2007).

Narrative text is written in past verbs, and uses everyday vocabularies because the story has already happened in the past time and it talks about the daily activities of the characters in the story. "Narratives typically use everyday vocabularies"(Schumm, 2006:23). The other characteristics of narrative text were given by Maharani (2007:68) as below:

"Use Past Tense.
- The purpose of text communicative is to amuse the reader with real experience or imagination.

- The structure of narrative text there are orientation, complication, resolution.

- Orientation consists of figure, time and place.

- Complication consists of the events or the problem turned to conflict.

- Resolution consists of solution the problem toward conflict that happened.

- Use conjunctions to put the events such as then, before, that, etc."

From the explanation above, we can conclude that the generic structure of narrative text consists of orientation, complication, and resolution. They must be integrated as a whole in order to make a complete story. About the coda which contains of lesson or moral value is not a must. Actually, the moral value has been told implicitly along with the story.

\section{METHODS}

This is a quantitative research which was used to count whether there was an increase in the students' ability in writing narrative text by using picture series or not.

The participants of this study was the eight grade students of SMP Negeri 3 Sindang Kelingi, Curup, Bengkulu in the 2014/2015 Academic Year, class 8C. They were 20 students, 13 girls and 7 boys.

The data collection tools used for this study was the students' final product and the data was in the form of students' writing score and classroom observations. 


\section{Analyzing Data Procedures}

In scoring the students' final products, scoring rubric adapted from Brown and Bailey (1984) as cited in Brown (2004;245) and ESL Composition Profile from Jacob et.al (1981) and Hartfiel (1985) as cited in Ito $(2011,29)$ were used. There are five aspects used as the criteria in the scoring rubric, including content, organization, vocabulary, grammar, and mechanics.

There were four categories used in this study in order to identify the level of students' ability in writing narrative in each aspect. They were excellent, good, fair, and poor in the range of scale from 1 to 20 . If the score of an aspect was more than 15 up to less than or equal $20(15<n<20)$, the competence of writing in terms of this aspect was described as excellent. The score of an aspect of composition was considered to be good if it is achieved more than 10 up to less than or equal $14(10<\mathrm{n}<14)$.
If the score was more than 5 up to less than or equal $10 \quad(5<n<10)$, it was interpreted as fair. If the score of an aspect of students' narrative writing was more or equal than 1 up to less than $4(1<\mathrm{n}<4)$, the competence of the students in this aspect was considered to be poor.

\section{FINDINGS AND DISCUSSION}

Findings

Since the score was reliable, the final scores of students' writing were obtained by calculating the average score of each aspect gained from the first and the second raters. From the calculation, the result showed that the average score of students' final scores was 73,56. This calculation also revealed that there were $90 \%$ of students who achieved scores above 75 , meaning that 18 students out of 20 students passed the Minimum Learning Mastery or Kriteria Ketuntasan Minimum (KKM). Table 1 shows the students' scores in the both cycles.

Table 1 : The Calculation of Students' Score in Cycle I

\begin{tabular}{|l|l|l|}
\hline No. & \multicolumn{1}{|c|}{ Students' Name } & \multicolumn{1}{c|}{ Students' Score } \\
\hline 1 & Student 1 & 60 \\
2 & Student 2 & 80 \\
3 & Student 3 & 75 \\
4 & Student 4 & 65 \\
5 & Student 5 & 80 \\
6 & Student 6 & 80 \\
7 & Student 7 & 70 \\
8 & Student 8 & 100 \\
9 & Student 9 & 70 \\
10 & Student 10 & 90 \\
11 & Student 11 & 70 \\
12 & Student 12 & 65 \\
13 & Student 13 & 100 \\
\hline
\end{tabular}




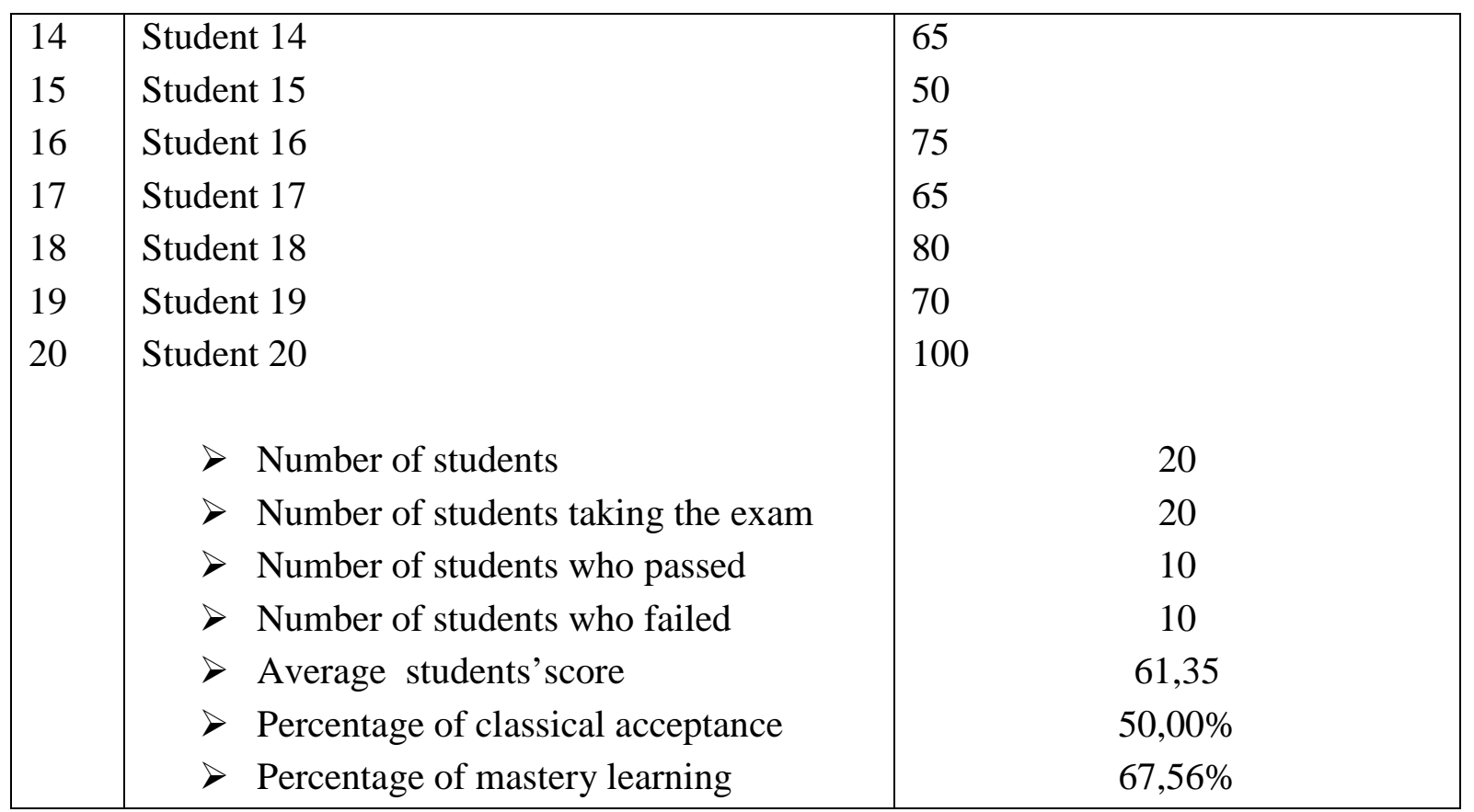

In Cycle I there were 20 students who showed that the average of the students, took the an exam, 10 students passed the score was 61,35 , while the percentage of the exam and 10 students failed because their classical acceptence was 50,00\% and the scores were under 75 .The analysis and percentage of the mastery learning was calculation of the students' score in Cycle I $\quad 67,56 \%$.

Table 2 : The Calculation of Students' Score in Cycle II

\begin{tabular}{|l|l|l|}
\hline No. & \multicolumn{1}{|c|}{ Students' Name } & \multicolumn{1}{c|}{ Students' Score } \\
\hline 1 & Student 1 & 70 \\
2 & Student 2 & 90 \\
3 & Student 3 & 85 \\
4 & Student 4 & 75 \\
5 & Student 5 & 90 \\
6 & Student 6 & 90 \\
7 & Student 7 & 80 \\
8 & Student 8 & 100 \\
9 & Student 9 & 75 \\
10 & Student 10 & 75 \\
11 & Student 11 & 85 \\
12 & Student 12 & 75 \\
13 & Student 13 & 80 \\
14 & Student 14 & 100 \\
15 & Student 15 & 90 \\
16 & Student 16 & 65 \\
\hline
\end{tabular}




\begin{tabular}{|c|c|c|}
\hline 17 & Student 17 & 80 \\
\hline 18 & Student 18 & 100 \\
\hline 19 & Student 19 & 85 \\
\hline 20 & Student 20 & 100 \\
\hline & $>$ Number of students & 20 \\
\hline & $>$ Number of students taking the exam & 20 \\
\hline & $>$ Number of students who passed & 18 \\
\hline & $>$ Number of students who failed & 2 \\
\hline & $>$ Average students'score & 84,50 \\
\hline & $>$ Percentage of classical acceptance & $82,97 \%$ \\
\hline & $>$ Percentage of mastery learning & $86,48 \%$ \\
\hline
\end{tabular}

In Cycle II, there were an increasing on the number of the students who passed the exam, namely 18 students and those who failed were only 2 students. The calculation of the students' score in Cycle II showed that the average score was 84,50 , while the percentage of the classical acceptance was $82,97 \%$ and the percentage of the mastery learning was $86,48 \%$.

The calculation of each aspect in writing showed that the students' ability varied in the aspect of content, organization, vocabulary, grammar, and mechanics. The average score of students score in terms of content was 18,65 . There was $80 \%$ of students (16 students out of 20 students) attained excellent category. The percentage of students achieving good category was $20 \%$ (4 students out of 20 students). Since the average score of students' score in terms of organization was 19,16, the students were considered excellent in organizing ideas and covering the generic structures of narrative texts. The number of students' whose scores were included into excellent category was $85 \%$ (17 students out of 20 students), $10 \%$ (2 students out of 20 students) were considered in good category, and $5 \%$ (1 student out of 20 students) was in poor category. In the aspect of vocabulary, the average score of the students' score was 16,03 , meaning that they could choose and use the vocabulary item well in their writing products. There was $85 \%$ (17 students out of 20 students) included in excellent category and 15\% (3 students out of 20 students) included in good category. The average score of the students' scores in the terms of grammar was 15,86 . There was $75 \%$ (15 students out of 20 students) were included in excellent category, $15 \%$ (3 students out of 20 students) were included in good category, and $10 \%$ (2 st dents out of 20 students) were in fair category. In the terms of mechanics, the average scores of the students' scores was 18,00 . There was $90 \%$ (18 students out of 20 students) were included in excellent category while $10 \%$ (2 students out of 20 students) were included in good category. In this research, the students' participation was also observed 
during the teaching and learning process conducted in each meeting. From the data collected, it is revealed that during the implementation of action in the two cycles, the students' participation was very good. In brief, the students did the procedures conducted in the teaching and learning process so the implementation of action to improve their ability in writing narrative texts could be conducted without any major obstacle. Also, from the questionnaires distributed, it was shown that the students had positive responses toward the teaching and learning process by using picture series.

\section{DISCUSSION}

From this study, the researcher discovered that the use of picture series improved the ability of writing narrative text of the VIIIC students of SMP Negeri 3 Sindang Kelingi. The research findings revealed that $90 \%$ of students (18 students out of 20 students) achieved scores more than 70 . It was also revealed that most students achieved more than or equal 15 in each aspect, meaning that most students were excellent in writing narrative text in terms of content, organization, vocabulary, grammar, and mechanics. It was also revealed that the students were actively involved in the teaching and learning activities. This achievement could not be separated from the use of picture series as the instructional media and the techniques employed to teach writing.

The consideration of the use of picture series is because students are usually interested in new things which can encourage them to pay attention and learn about it. They can also imagine the chronological events of the story in the picture immediately. These picture series also can elicit the power of acquiring new language. As Diaz Rico (2004:203) stated to access motivational power, that the second language must reconnect with a symbolic system that is subdominant in the first language but lies dominant, connected with powerful emotions, in sense waiting for a portal expression. In addition, a new atmosphere should be brought in teaching narrative to emerge the students' interest and motivation. So they were hoped to be able to write a meaningful composition and academically could give a benefits to their achievement.

The picture is effective to use because it can attract the students and give them motivation in writing, and through picture the students can get enough stimuli (Wright, 1989:2).

When the students' attention was attracted and they could feel that the atmosphere of the teaching and learning process were 'lived' and interesting, they would participate in the teaching and learning process enthusiastically. According to Oller (1979:105), "no one seems to doubt that attitudinal factors are related to human performances". So, using pictures to attract the students' attention will be effective to stimulate their activities in writing narrative text.

Giving any help to the students to get any idea to write is very useful for the students because mostly they are difficult to start writing when they do not know what they have to write. By giving picture series, 
they can see some interesting pictures, so they can get some ideas in starting to write by imagining the things happen based on the pictures. They can start to think and imagine the story that will be written by them based on the pictures that have been given.

In teaching and learning process, especially writing, it needs more time. Thus, the extra attention should be given by the teacher. While teaching how to write a narrative text by using picture series, the first step the teacher should do is by having brain storming to build the students' memory of narrative that they have already got. It means the teacher wanted to know how far the students knew or remembered about the material or to stimulate their mind to recall their previous knowledge. And it worked effectively.

Secondly, the teacher presents the material, narrative itself. The teacher explained it efficiently and in an easy way, so the students can understand. The teacher also showed the picture series in order to build the students' imagination of the story they are going to write.Then the teacher explored some information based on the picture series and discussed it together with the students, especially about the vocabulary that will be used in writing the narrative text.

Finally, the teacher helped the students in producing their narrative writing by giving any help that needed. The student explored their imagination while writing the narrative text based on the pictures given. Pre-teaching vocabulary is the other technique which might contribute to the improvement of students' language acquisition. To be successful in writing a text, the students should have a good understanding about the vocabulary and be able to use them without continuously thinking about the meaning.

The students' ability in writing narrative text might also be enhanced by an appropriate teaching technique implemented in the classroom. In this study, the researcher implemented process genre approach which was the synthesize of product, process, and genre approaches (Badger and White, 2000 cited in Nurjanah, 2011:84 in Nurcahyasari, 2014:08). By implementing process-genre approach, the students could learn and ensure their concept of narrative text from the model of texts presented. During the Joint Construction of Text (JCoT), the students' ability in writing narrative text was trained by composing narrative text in pairs based on the picture series given by the teacher.

Finally, the students were honing their skills in writing narrative text by composing another story individually based on the picture series displayed during the Independent Construction of Text (ICoT) stage.

\section{CONCLUSION AND SUGGESTION}

Conclusion

In accordance with the overall findings and discussion in this study, the implementation of picture series in teaching and learning how to write narrative text improved the students' ability in writing narrative text. The students' improvement was discovered through the students' scores after the 
implementation action, in which $90 \%$ of the student attained scores above 70 . Most of their writings were excellent in terms of content, organization, vocabulary, grammar, and mechanics. It proved that the implementation of picture series could be an alternative to help students in improving their ability in writing narrative texts. This improvement might also be supported by the intrinsic motivation of the students to learn which was stimulated by the using of picture series as the instructional media.

Picture series could be effective to enhance students' writing ability if the teacher applied a teaching technique which was appropriate to the students. Based on this study, process-genre approach was suggested to be applied in the teaching and learning activities. In these activities, writing was emphasized in the product of writing which concerned on knowledge about language. The process-genre approach applied in the present studies also views writing in terms of the skill in using language which was expressed through the process of writing. Also, writing was viewed from the context and purpose of writing based on the genre of the text.

\section{SUGGESTION}

Suggestion

After conducting an analysis and reflection towards the implementation of picture series in this study, there are some suggestions made for the teachers, school principals, and the future researchers to conduct the follow up of the result of this study.
Because the implementation of picture series was successfully in improving the students' ability in learning English, especially in writing narrative text, it is suggested for English teachers to use this media in their teaching and learning activities. This media can be used not only in teaching writing narrative text, but also fostering students' competence in some other kinds of texts for other skills. It is also recommended for English teachers for adjusting the appropriate picture series to the level and characteristics of the students. It is also essential for the teachers to select the appropriate teaching technique before implementing the teaching and learning activities by using the media.

For school principals, it is suggested to provide facilities to support the English teachers in implementing picture series in their teaching and learning activities. Some main facilities which are needed in the implementation of picture series are LCD projector, computer / laptop, and loudspeakers.

The implementation of picture series in this study might also offer a satisfying result when it is applied in the other subjects and or by using another material and technique. Thus, it is recommended for the future researchers to develop the implementation of picture series and explore many other things to the teaching and learning by using the media. 


\section{REFERENCES}

Brown, H.D. 2004. Language Assessment: Principle and Classroom Practices. New York: Pearson Education, Inc.

Dewi, Kartika. 2012. Students' Ability in Writing Narrative Texts in Form AnAnecdote by Using A Picture at The Eight Grade Students of SMP N 10 Muaro Jambi. (Online) in Joumal. unbari. ac.id. accessed on April 25 2015.

Diaz-Rico. 2004. Types in Text English 3. South Yarra: Macmillan Education Australia PTY LTD.

Herman, David. 2007. Narrative. Cambridge: Cambridge University Press.

Kirszhen, Laurie G. and Mandell, Stephen R. 2008. Focus on Writing Paragraph and Essays. Boston: Bedford/St. Marin's.
Maharani, Ida. 2007. How to Write Effectively. Yogyakarta: Citra Aji Parama.

Nunan, David. 2003. Practical English Language Teaching. New York: Mc Grawt-Hill.

Nurcahyasari, Febriyanti and Irawati, Enny. 2014. Using Music Videos to Improve The Ability in Writing Narrative Texts of The Eleventh Graders in SMA Negeri 4 Malang. (Online) ( library.um.ac.id / free-content / save doc pub.php /narrative.doc) accessed on April 25 2015.

Oller, J.W. 1979. Language Test at School. London: Longman Group Ltd.

Pardiyono. 2007. Teaching Genre-Based Writing. Yogyakarta: ANDI 